\title{
GRAPHO-ANALYTICAL MODELING OF PROCESSES OF INTERACTION OF ELEMENTARY COMPONENTS OF A MANAGEMENT PAIR
}

\author{
Dzvinchook D. I., doctor of philosophy sciences, professor, \\ Liutyi M. O., master of public government and administration, \\ Petrenko V.P., doctor of economic sciences, professor \\ Ukraine, Ivano-Frankivsk national technical university of Oil and Gas
}

\section{DOI: https://doi.org/10.31435/rsglobal_ijite/30112018/6208}

\section{ARTICLE INFO}

Received 19 September 2018

Accepted 22 November 2018

Published 30 November 2018

\section{KEYWORDS}

control,

subject,

object,

coefficient,

subjectivity,

continuum,

partner,

relationship,

dialogue,

communication,

intelligence,

morality,

purpose,

task,

effect.

\begin{abstract}
In order to analyze and justify the choice of the recommended modes of interaction of people in organizational entities, the article covers the main possibilities of increasing the effectiveness of human interaction on the basis of interpreting a typical management pair in the form of two elementary components that can interact in the "subject-object", "subject-subject", "object-subject" and "object-object" modes, taking into account the fact that each component is characterized by a certain level of subjectivity. At the same time, the authors take into account the fact that during the life of a person and its life cycle in an organizational formation the level of subjectivity of any person varies within the boundary of the linear continuum object - subject, and its subjectity in organizational formation is defined by no means other, as the current state of the ratio of the number of formal and informal influences of the individual as a subject to other members of the organization to the number of the same effects on it as an object from other members of the organization. Due to the fact that the life cycles of the elementary components are characterized by the presence of each of the periods of increase in subjectivity with the achievement of each peak value and the subsequent gradual loss after release or retirement, it is demonstrated that the joint and equally effective activity of the components is possible only provided that they maintain the subject-subject mode of interaction, which corresponds to the dialogue of the two parties, rather than management of or management by one side of the other. Using the superposition of graphanalytic dependencies of Dunig-Kruger and changes in subjectivity throughout life, it is proved that the basic condition for the implementation of such a managerial dialogue is the awareness of both components of the managerial pair of the fact that the concept of the subject loses meaning without the existence of the object, and therefore maintaining the process of dialogue-cooperation is possible only under the condition of equality and freedom of the participants and the inter-orientation of each of the partners as the subject, the tool for establishing partnerships is management on the basis of the dialogue communication process with the mutual recognition of each of the participants in their freedom, equality and value - subjectivity. It has been established that the priority factors determining the results of the operation of a typical management pair are not the structure and the relationship between its constituent elements, but the intellectual, moral and psychological characteristics of these elements and the awareness of the latter as partners that jointly solve the problem with the achievement of mutually established and harmonized goals.
\end{abstract}

Citation: Dzvinchook D. I., Liutyi M. O., Petrenko V. P. (2018) Grapho-Analytical Modeling of Processes of Interaction of Elementary Components of a Management Pair. International Journal of Innovative Technologies in Economy. 8(20). doi: 10.31435/rsglobal_ijite/30112018/6208

Copyright: (C) 2018 Dzvinchook D. I., Liutyi M. O., Petrenko V. P. This is an open-access article distributed under the terms of the Creative Commons Attribution License (CC BY). The use, distribution or reproduction in other forums is permitted, provided the original author(s) or licensor are credited and that the original publication in this journal is cited, in accordance with accepted academic practice. No use, distribution or reproduction is permitted which does not comply with these terms. 
Problem statement and its connection with important scientific or practical tasks. The problems of organizing the effective interaction of people in various fields of their joint activity and livelihoods have been and continue to be the subject of attention of many foreign and domestic researchers in search of opportunities to improve the processes of management of diverse and multilevel organizational entities as the basis for obtaining better results of these entities. After all, it is the level of interaction and relationships of the constituent elements of any system that determine the effectiveness and efficiency of the latter, and due to that the issue of improving the management of the interaction of these elements continues to remain relevant.

An analysis of recent research and publications, the allocation of previously unsettled parts of the general problem to which this article is devoted. Analysis of publications in the field of research shows that most researchers interpret the process of managing one person to another in the traditional form of interaction of two components of the typical management pair (TMP) "subject object" [1], "the leader - subordinate" [2,3] or "leader-follower" [4, 5], covered by the feedback. The authors of the article [6] considered other possible variants of interaction of the components of the model "subject - subject" and "object - object", and even an option, when the "object" affects the "sub" object ". At the same time, however, most researchers remain at positions of allocation of predetermined roles of the subject and object, or the head and the executor, the one who accepts and the one that performs managerial decisions, to the participants in the process of interaction of the components of the TMP. And that neglects the fact that in the process of functioning of a TMP and the life of any person (both subject and object), the latter changes, acquiring or losing certain characteristics, knowledge, experience, beliefs, values, etc. However, changes in the characteristics of people - the components of the TMP - will obviously condition and change the relationship between them, which will cause changes in the results of their interaction.

Formulating the goals of the article. The purpose of this work is to justify the recommended modes of interaction between the participants in management processes in organizations based on the subject-subject relationships.

Presentation of the main research material. Evidence of the fact that any person changes throughout life is undeniable. Therefore, on the basis of the fact that a person during an active professional life as a result of continuous education, self-development, growing experience and confidence in its forces is changing and gradually increasing its professional, including management and leadership potential, one can assume that any person has the inherent trend of its gradual changes from the initial state of the object of influence (parents, educators, teachers, instructors, managers, etc.) in the direction of forming a certain level of personal subjectivity (leader, manager of the group, unit, department, organizations and so on.).

Consequently, assuming that within the framework of a certain organizational formation with the number of $\mathrm{N}$ employees, under the coefficient of subjectivity $\left(\mathrm{K}_{\mathrm{S}}\right)$ of any of its employees, we propose to understand the current state of the ratio of the number of its formal and informal influences as a subject to other members of the organization to the number of such effects and influences on this employee as an object from other members of the organization, then in a formalized form this coefficient is described by the following expression:

$$
\mathrm{K}_{\mathrm{S}}=\mathrm{N}_{(\mathrm{F}+\mathrm{NF})} / \mathrm{n}_{(\mathrm{F}+\mathrm{NF})},
$$

where $\mathrm{N}_{(\mathrm{F}+\mathrm{NF})}$ - the number of channels of formal and informal influence of the person on the members of the organization as a subject, $\mathrm{n}_{(\mathrm{F}+\mathrm{NF})}$ - the number of channels of formal and informal influence on the person from other members of the organization.

Thus, the coefficient of subjectivity of any employee of the organization can vary within $\min \leftrightarrow$ max depending on its official status (formal connections and communication) and the ability to establish relationships with employees (informal connections and communications).

Taking into account this assumption it seems quite justified to illustrate the development of personality in the form of a vector that shows the direction of changing the characteristics of a person from the state of the object of external influences of a certain set of subjects to the gradual acquisition of a certain level of subjectivity, when the person gets the opportunity to influence other persons in its organizational environment due to intelligence, acquired knowledge, obtained professional experience and given status in the hierarchy.

The continuum of transformation of personality from the state of the object of management to the state of the subject of management is presented in Figure 1. The figure demonstrates the obvious process of the gradual transformation of the individual, when the latter, according to M. Berdyaev, by 
means of cognition turns into "... not an object among the objects and not a thing among things. It becomes the subject among subjects, ..." [7], that is, it increases its ability to influence others. After all, in the opinion of the same author, formulated in 1934, it is the one who knows "... as an existential subject inevitably combines thought and will, contemplation and work, theory and practice" [8]. That is, it is in the processes of cognition that a person forms a unique list of the above characteristics, thus approaching to modern models of managers leaders with a high level of subjectivity [9], which distinguish it from an object /objects with a lower level of subjectivity.

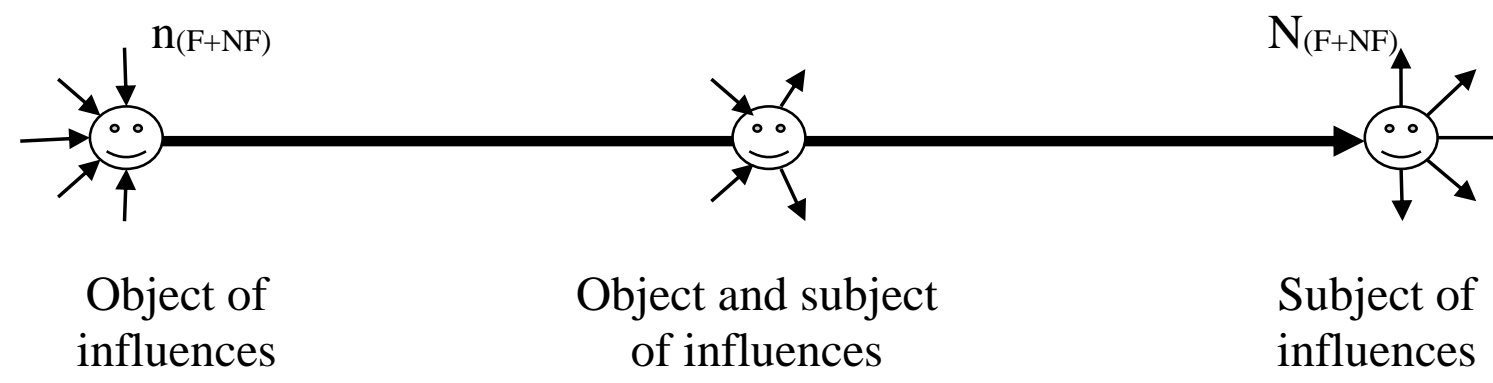

Fig. 1 Continuum of object-subject transformation of personality

In this case, the theoretical life cycle of any person by the value of the coefficient of subjectivity $\mathrm{K}_{\mathrm{S}}$ in the function of time $\mathrm{K}_{\mathrm{S}}=\mathrm{F}(\mathrm{t})$ can be interpreted as the set of curves presented in Figure 2.

Level of subjectivity

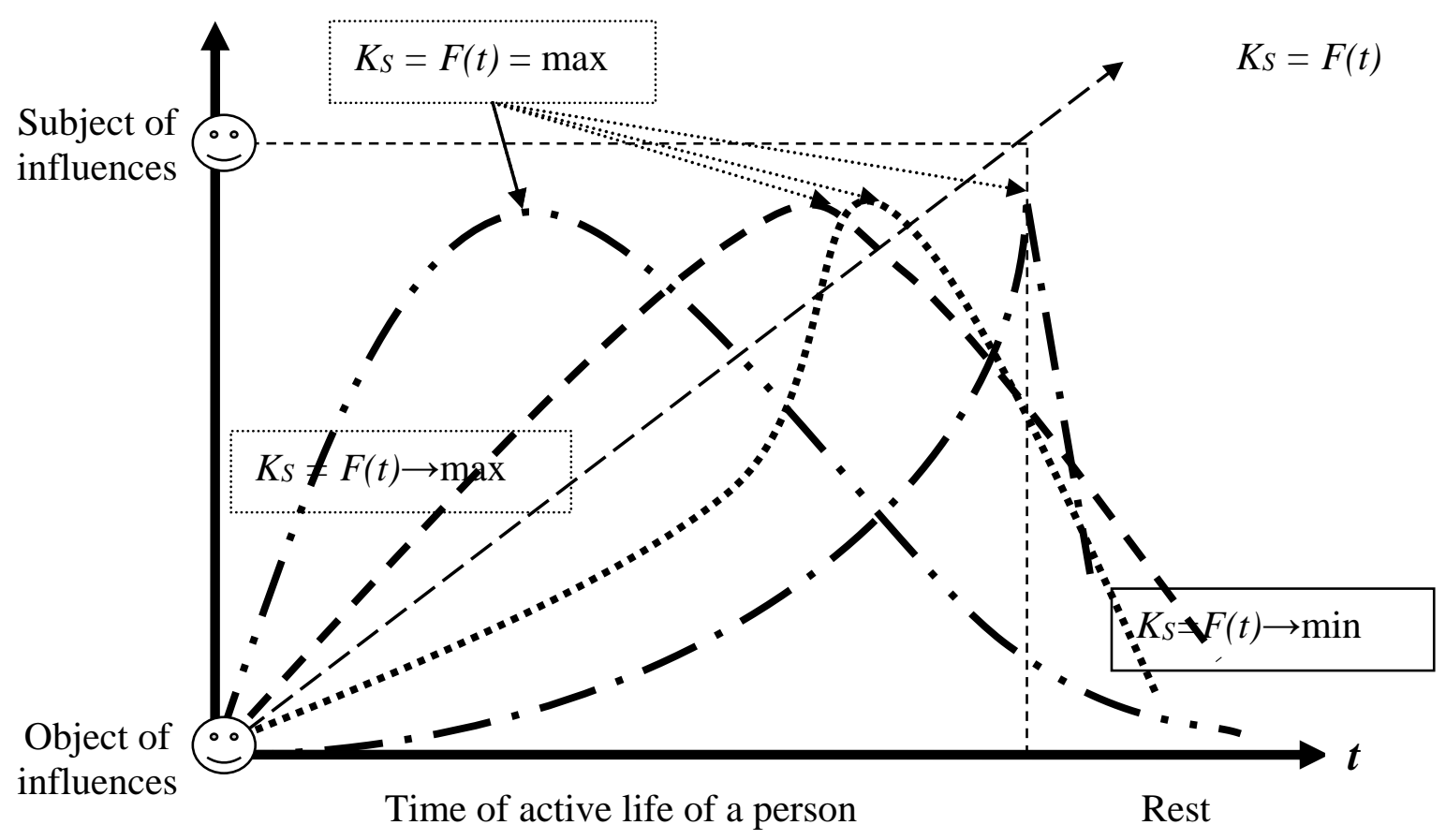

Fig. 2. Versions of changes in the level of subjectivity of the individual $K_{S}=F(t)$ in the process of its life

Characteristic general features of any set of life cycle options for personnel of an organization are the presence in each of them of a sequence of periods of increasing the subject's identity of the person $\mathrm{K}_{\mathrm{S}}=\mathrm{F}(\mathrm{t}) \rightarrow \max$, reaching the peak value $\mathrm{K}_{S}=\max$ and gradual loss of subjectity after release or exit for retirement $\mathrm{K}_{\mathrm{S}}=\mathrm{F}(\mathrm{t}) \rightarrow$ min.

With all possible variety of examples of the development of the subjectivity of $\mathrm{N}$ individuals during their joint active life in the organizational system, which is common to all the constituents of 
the TMP system, brought on figure 2 it remains necessary to maintain the process of their interaction in such a mode when their joint work will be resultative and effective.

It was in this context that the authors of the paper [6] carried out a comparative analysis of the variants of interaction between the components of the TMP and formulated recommendations on the benefits of their interaction in the mode of subject-subject relationships as such that guarantee the highest effectiveness, provided that the formal subject of the system is capable of effectively realizing the tasks of the subject in interaction with persons with a lower level of subjectivity, that is, an object or a certain set of objects.

It should be noted that the conclusions formulated in this paper are confirmed by the results of both ancient and contemporary research in other scientific fields.

Thus, M. Berdyaev, in the above-mentioned work, "I and the world of objects", based on the assertion that communicating with the object does not require interdependence, came to the conclusion that in reality "Communication is possible only with "I", which for me is "You" and requires interdependence, i.e. the activity "you". < .. > Loneliness overcomes only in the communication between "I", communication between individuals, between "I" and "You", not in an objective society, but in "We" [8]. That is, if the subject of TMP is endowed with the "I", then mutually effective communication with its object is possible only when giving the latter with the sign of the subject "You", and the system of TMP in general - a sign "We", which fully corresponds to the modern the interpretation of the subject-subject relations between people.

The author of the study in the field of socio-philosophical analysis of the joint activities of people [10] also concluded that only during the subject-subjective interaction of the two parties, their joint activities will commence with activity of participants, and the process of such interaction was determined by it in terms of dialogue communication, not management.

Thus, taking into account the above mentioned concept of the coefficient of subjectivity (1), we can come to the conclusion that it is the dialogue that is the most effective form of communication and cooperation of the system of two entities with different coefficients of subjectivity, provided that they are mutually determined in such quality, when each participant sees in himself and in the other a free and a unique personality. The main condition for the implementation of such a management dialogue is the awareness of both subjects of the fact that the concept of the subject loses meaning without the existence of the object, and therefore maintaining the process of dialogue-cooperation is possible only if the equality and freedom of the participants and the orientation of each partner on the subject, not the object exist. After all, each person is an entity only as much as it possesses consciousness and self-consciousness that determines the free choice of its goals and the necessary actions for their implementation. The main tool for establishing partnerships between elementary components is management on the basis of a dialogue communication process with the mutual recognition of their freedom, equality and value - subjectivity.

At the same time, the only prerogative of the subject of management in the system TMP remains its active ability to effectively implement the functions of the subject in interaction with individuals with a lower level of subjectivity, that is, an object or a certain set of objects.

Consequently, the main tool for effective interaction of the components of the TMP in the process of realization of the object and the need to achieve the goal is management on the basis of dialogue between them with the necessary, purposeful exchange of all appropriate types of business, social and technological information, and the main condition is the mutual perception of the subject and object of each other as subjects of the dialogue communication process with the mutual recognition of their freedom, equality and value - subjectivity.

Failure to fulfill the condition of perception of the subjectivity of each other by the TMP components precludes the possibility of establishing an equal management dialogue in the mode of the subject-subject with the exchange of necessary and reliable information, that is, violates inter-entity interaction in favor of the interaction of the subject-object with loss a system of potentially achievable efficiency and effectiveness. The reason for this is the formulation in [11] of such a characteristic of any subject as "... the value attributed to him by another person or by himself". It turns out that assessment that a person gives to itself, and how it is assessed by others, in most cases, differ from each other.

An irrefutable evidence of the consequences of such a rejection are examples of manifestations in the organizational formations of the well-known Dunning-Krueger effect [12], when, as a result of managerial mistakes, acquaintances, political expediency, career ambitions, the case, etc., individuals fall into positions that require high level of subjectivity, not being prepared for such a responsibility either professionally, morally or socially. The analysis of the causes and effects of manifestations of this effect, made in [13], proved that such manifestations are conditioned by the difference between the two values 
of the coefficient of personality of the person - the real (KSR), which is inherent in her according to other members of the organization (leaders, colleagues and subordinates) and virtual (KSV), which is either justified or mistakenly attributed to the person himself.

Figure 3 shows a graphical interpretation of the Daning-Kruger effect in the form of a theoretical dependence of a person's confidence in his professional abilities and psychological readiness to perform professional duties and tasks with a high level of necessary subjectivity as a function of the time during which it develops through knowledge.

The superposition of the theoretical dependence $K_{S}=F(t)$ ) (Figure 2) on the process of person's establishment by a specialist and expert (Figure 3) shows that this component of the professional development of a person corresponds to the stage of growth of the subjectivity $K_{S}=F(t) \rightarrow$ max and the achievement of the peak value $\mathrm{K}_{S}=\max$ in the organization, and the manifestation of the DaningKruger effect should be considered non-stereotyped, a deviant case of an increase in the status position of a person in an organization without a corresponding increase in its subjectity.

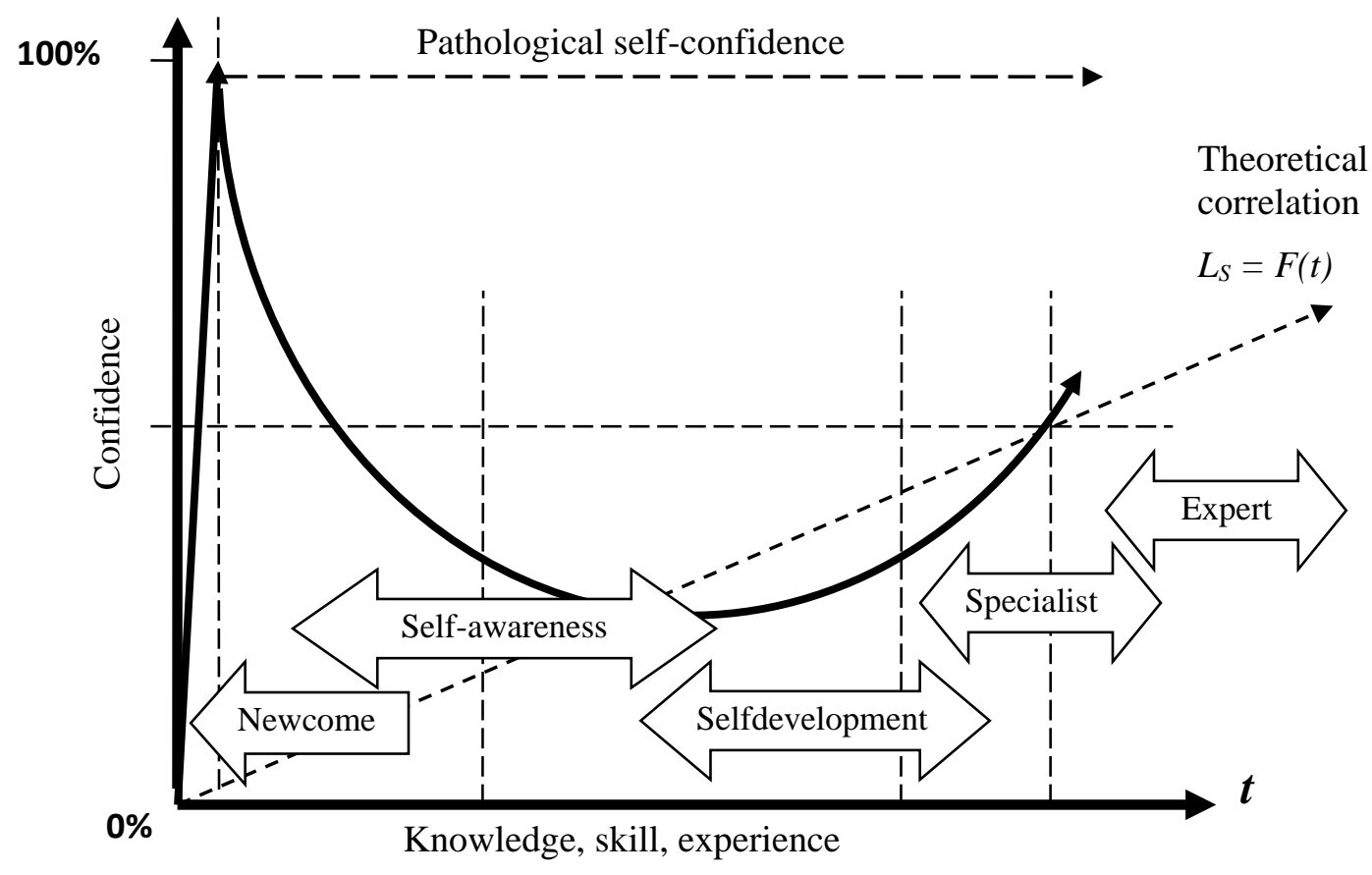

Fig. 3 Interpretation of a diagram of the stages of development of a personality in time under the conditions of the Danning-Kruger effect (Ref. [13]).

If, on the basis of our assumptions about the gradual growth of the real coefficient of subjectivity of the components of the TMP, a superposition of the dependencies $\mathrm{K}_{\mathrm{S} 1}=\mathrm{F}(\mathrm{t})$ and $\mathrm{K}_{\mathrm{S} 2}=\mathrm{F}(\mathrm{t})$ on the basis of the combination of the axis of influence $\mathrm{S} 1$ with the axis of time $\mathrm{S} 2$ and vice versa is to be performed (Figure 4), an interesting result that demonstrates that changes in the values of the coefficient of subjectivity of both components over time will fall into the zone where their coefficients of subjectivity $\mathrm{K}_{\mathrm{S} 1}$ and $\mathrm{K}_{\mathrm{S} 1} \rightarrow$ max can be obtained.

If, in the same coordinates, we construct the theoretical dependences of the two components of the TMP even under the condition of manifestations of their effects on the Dunning-Kruger effect, then it becomes obvious that, if they are properly developed through self-awareness and professional perfection, their coefficients of subjectivity will eventually also be displaced in zone of maximum values $\mathrm{K}_{\mathrm{S} 1}$ and $\mathrm{K}_{\mathrm{S} 1}$.

That is, the condition of getting into the zone in which the coefficients of the subjectivity of $\mathrm{K}_{\mathrm{S}}$ of both components of the TMP acquire the maximum value is the intellectual, professional and moral development of the latter, which ensures awareness of each of the participants of the necessity and expediency of cooperation in the mode of the subject-subject

Thus, in the classical structure of a typical managerial pair, "subject-object" or "leadersubordinate", the nature of the interaction of its constituents will be determined not so much by the structure and links between its elements, but by the nature of communication between these elements. 
At the same time, the latter will be determined by the estimates of these elements of each other, which will depend on their intellectual, professional, psychological and communication readiness to cooperate in the recommended mode for any values of their coefficients of subjectivity $\mathrm{K}_{\mathrm{S1}}$ and $\mathrm{K}_{\mathrm{S2}}$.

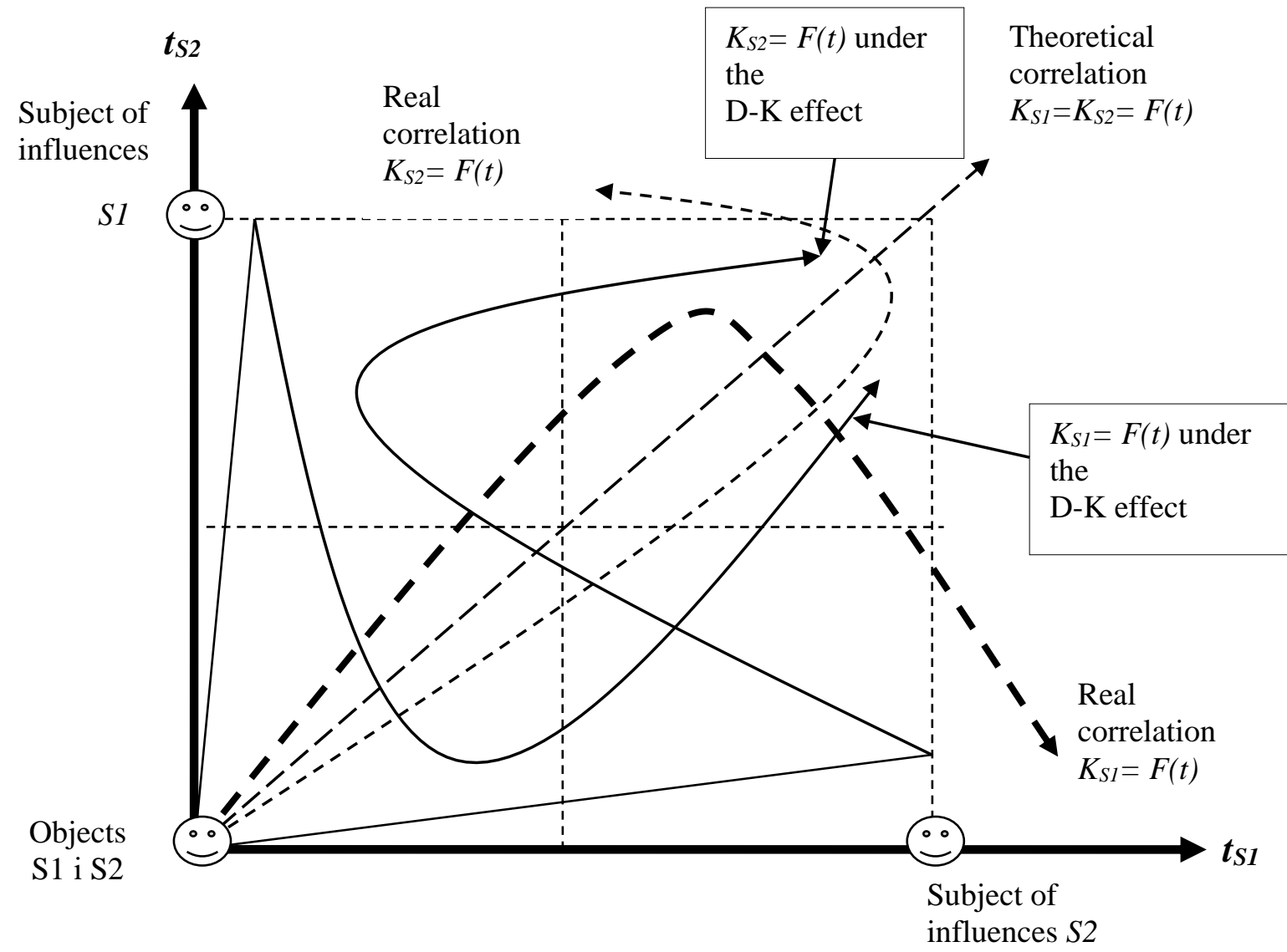

Fig. 4 Variants of changes in the level of subjectivity of a $L_{S}=F(t)$ personality in the process of its life

The lack of such awareness causes changes in the modes of interaction with others, even with the same values of $\mathrm{K}_{\mathrm{s}}$. Therefore, all of the foregoing allows us to construct a plane model of the interaction variants of the TMP components in the form presented in Figure 5.

The division of the plane of mutual perception and interaction of the components of the TMP into 4 quadrants allows us to distinguish the same 4 characteristic zones that were identified and justified in [6], namely:

- "Holocracy" - in the quadrant1, components S1 and S2 interact in the mode of joint nonsubordinate functioning of "object-object";

- "Autocracy" - in quadrant 2, components S1 and S2 interact in the mode of dominant influence of one component over another "subject-object";

- "Synarchy" - in the quadrant, 3 components S1 and S2 interact in the mode of coadministration "subject-subject";

- "Subocracy" - in the quadrant, 4 components S1 and S2 interact in the mode of dominant influence of intelligence and the recommendations of the object on the managerial decisions of the subject, that is, "object-subject". 


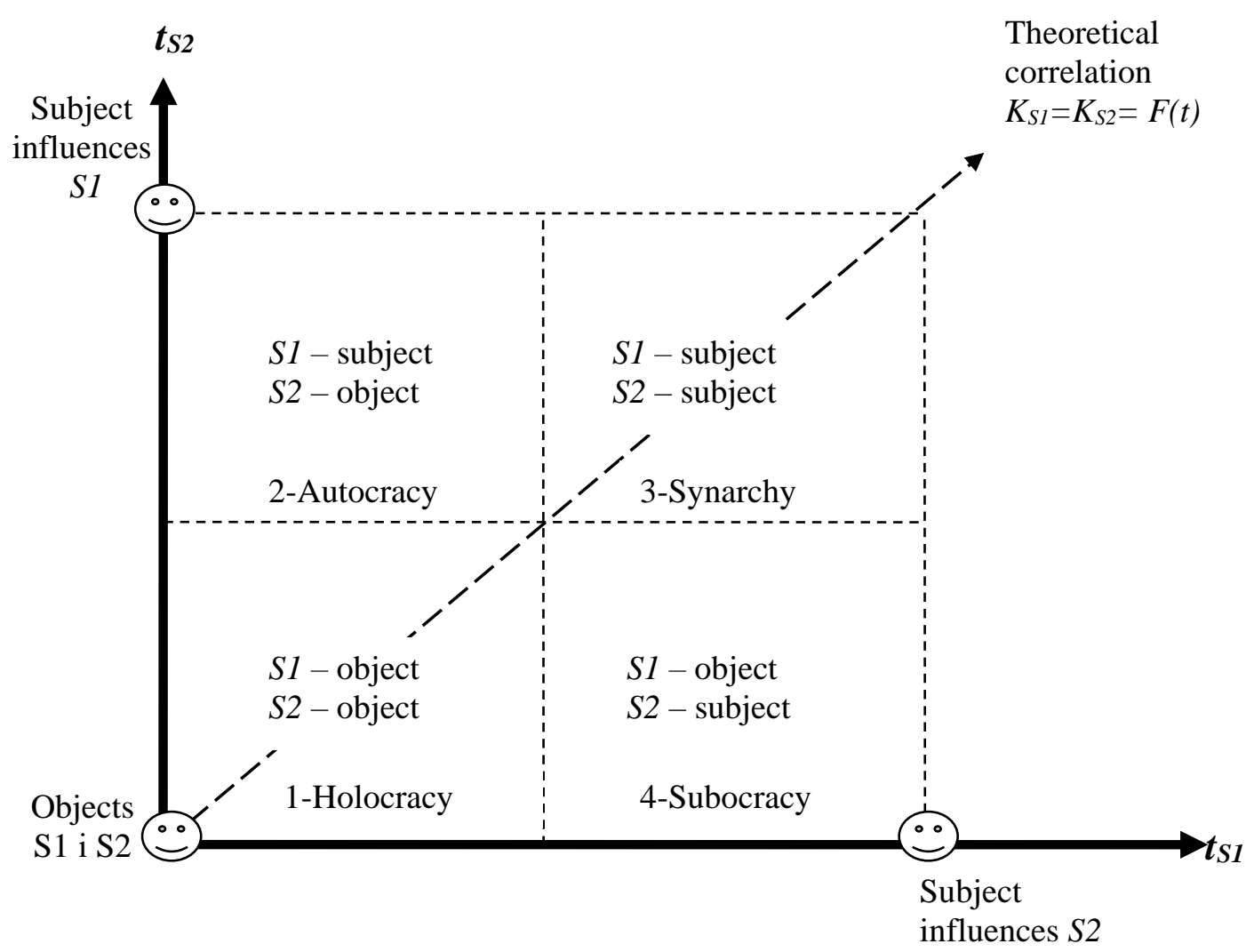

Fig. 5. Plane model of variants of possible interactions of TMP components

As it was proved in [6], potentially the most successful interaction is expected as a result of manifestations of the phenomena of synthelectic (common thinking) and synarchy (joint management) and the emergence of "integral intelligence" of a TMP, which may result in the effect of synergy, while in all other variants there are no grounds for the synergistic effect of cooperation between the parties.

Consequently, if in [6] the analysis of the interaction of the elementary components of the system was based on the analytical dependencies of the classical structure of the subject-object known in technical cybernetics, which took into account the influence of the intelligence of the components on their transformation coefficients and on the overall coefficient of transformation of the system, then in our the case it was also revealed that such an important psychological element as perception-nonacceptance of the components of TMP of their partners as subjects is involved in this process - the psychological factor that determines their structure of their connections and relationships. That is, each component of TMP using its own intelligence, goals and values determines the structure of interactions through direct and reverse influences. The condition of effective interaction is the determination of all elements of the system of one type of structure and relationships, goals and values.

Otherwise, any "properly" designed structure of the system, filled with living people, will instantly be transformed by the latter using its perception and understanding of the situation, the reliability of the information received and provided, transparency and type of communication processes, etc.

Indirect confirmation of the effectiveness of using the recommended control regime in the TMP can be considered such already known flat models as J. J. Leader's model for Toyota [14, p. 237], the typology of groups by Yu. Navruzov [15], the model of decision-making by consensus M. Roberto [16], the model of behavior in the conflicts of Thomas-Kilmenn [17] et al, in which the best types of interaction between leaders with subordinates in different situations are realized it is on conditions of the quadrant with the dominant mode of interaction "subject-subject".

Conclusions from this study and prospects for further exploration in this field. Consequently, the above graph-analytic constructs of possible variants and dynamics of changes in the characteristics of the participants in the management process within the framework of a typical management pair allow us to conclude that the priority factors that determine the performance of a typical management pair are not the structure and the relationship between its constituent elements, 
but the intellectual, moral and psychological characteristics of these elements and the awareness of each other as partners that jointly solve the problem of achieving jointly set and harmonized goals.

Due to this:

- the recommended mode of interaction of the elementary components of a typical management pair is the relationship between the "subject - subject", because its qualified use by the entity will provide the maximum possible results of joint activities with the formation of positive relationships between partners;

- the main tool for establishing partnerships between the elementary components is management on the basis of a dialogue and communication process with the mutual recognition of their freedom, equality and value - the coefficient of subjectivity of a person in the organization $\mathrm{K}_{\mathrm{s}}$;

- the mode of interaction of elementary components in the variant "subject - subject" should be dominant in the management process, while control in the modes "subject - object", "object - subject" and "object-object" is allowed only in the case of situations that require only their temporary use.

Based on the foregoing, it would be expedient in the future to create and test instruments to determine the person's propensity to lead or co-operate with others in the above-mentioned regimes, as well as to develop and implement a program of experimental studies to assess the coefficients of the real KSR and the virtual KSV subjectity of the person organizational formations and their compliance with these factors in their status in these organizations.

\section{REFERENCES}

1. Pashko L. A. Vidnosyny u formati «subiekt upravlinnia - obiekt upravlinnia»: napriamy harmonizatsii / L. A. Pashko // Nauk.-inform. visn. z derzh. upr. - 2010. - № 4. - S. 14-18. http://www.academy.gov.ua/ej/ej12/txts/10plasov.pdf

2. Kuzmin O. Doslidzhennia modeli vzaiemodii kerivnyka z pidlehlym: metodychni pidkhody / O. Kuzmin, N. Mala // Rehionalna ekonomika. - 2005. - №2. - S. 225-231.

3. Pashko L. Harmonizatsiia upravlinskykh vidnosyn u formati «kerivnyk - pidlehlyi»: realnist chy utopiia? / Liudmyla Pashko // Visn. NADU. - 2011. - № 4. - S. 56-65. http://visnyk.academy.gov.ua/wpcontent/uploads/2013/11/2011-4-9.pdf

4. Goldsmit, M. Peremykaisia. Stan tym, kym khochesh buty / Marshal Goldsmit, Mark Reiter ; per. z anhl. Natalii Valevskoi. - K.: Nash format, 2017. - $240 \mathrm{~s}$.

5. Lipentsev A. Rozvytok liderstva v orhanakh publichnoi vlady u konteksti zavdan nadannia yakisnykh administratyvnykh posluh: teoretychni ta metodolohichni aspekty / A. Lipentsev // Naukovyi visnyk «Demokratychne vriaduvannia». - 2013. - Vyp. 12. http://lvivacademy.com/vidavnitstvo_1/visnik12/fail/Lipencev.pdf

6. Dzvinchuk D. I. Shchodo teoretychnoho analizu i utochnennia poniattia «typova upravlinska para» yak osnovy rozvytku i udoskonalennia publichnoho upravlinnia / D. I. Dzvinchuk, O. V. Liutyi, V. P. Petrenko // «Humanitarnyi visnyk Zaporizkoi derzhavnoi inzhenernoi akademii»: zbirnyk naukovykh prats. - 2016. - Vyp. 67. - S. 191-201.

7. Berdiaev N. O rabstve y svobode cheloveka / N. Berdiaev // [Elektronnyi resurs]. - Rezhym dostupu: http://vehi.net/berdyaev/rabstvo/index.html

8. Berdiaiev N. Ya y myr obъektov. Opыt fylysofyy odynochestva y obshchenyia / N. Berdiaev // [Elektronnyi resurs]. - Rezhym dostupu: http://vehi.net/berdyaev/mirobj/02.html

9. Dzvinchuk D. I. Ekonomika znan i neobkhidni zminy v modeliakh liderstva / D. I. Dzvinchuk, M. O. Liutyi, V. P. Petrenko // Zb. nauk. prats «Humanitarnyi visnyk Zaporizkoi derzhavnoi inzhenernoi akademii». - 2016. - Vyp. 64. - S. 44-60.

10. Arsentieva H. O. Spilkuvannia yak sumisna diialnist liudei: sotsialno-filosofskyi analiz: dys. ... kand. filos. nauk: spets. 09.00.03 «Sotsialna filosofiia ta filosofiia istorii» / H.O. Arsentieva. - Zaporizhzhia, 2001. - $170 \mathrm{~s}$.

11. Arsentieva H. O. Struktura i elementy fenomena spilkuvannia / H. O. Arsentieva // Aktualni problemy filosofii ta sotsiolohii. - 2015. - №0. - S.7-10.

12. Kruger, J. Unskilled and unaware of it: How difficulties in recognizing ones own incompetence lead to inflated self-assessments / Kruger, Justin; Dunning, David // Journal of Personality and Social Psychology, Vol 77(6), Dec 1999, 1121-1134. http://dx.doi.org/10.1037/0022-3514.77.6.1121

13. Dzvinchuk D. I. Shchodo proiaviv efektu Daninha-Kriuhera v systemi upravlinnia Ukrainskoiu derzhavoiu / D. I. Dzvinchuk, V. P. Petrenko // Teoriia ta praktyka derzhavnoho upravlinnia. KharRIDU. - 2017. №1(56). - Rezhym dostupu : http://kbuapa.kharkov.ua/e-book/tpdu/2017-1/index.html

14. Laiker Dzh. Dao Touota: 14 pryntsypov menedzhmenta vedushchei kompanyy myra / Dzheffry Laiker; Per. s anhl. - 2-e yzd. - M.: Alpyna Byznes Buks, 2006. - 400 s.

15. Navruzov Yu. Komandni roli: vprovadzhuiuchy zminy: Oryhinaly mystetstva [Tekst] / Yu. Navruzov // Kyievo-Mohylianska Biznes Studiia. - 2002. - № 2. - S. 20 -25

16. Michael A. Roberto. Why Great Leaders Don't Take Yes for an Answer: Managing for Conflict and Consensus [Текст] / Roberto, Michael A. // [Електронний pecypc] GovLeaders.org. - Режим доступу: http://govleaders.org/no_yes_men.htm

17. Introduction to the Thomas-Kilmann Conflict Mode Instrument (TKI) [Електронний ресурс] CPP. The people development people. - Режим доступу: www.cpp.com 